\title{
Biblical Philosophy: an Introduction
}

\author{
Mark Cauchi $^{1} \cdot$ Avron Kulak $^{1}$
}

Published online: 23 December 2015

(C) Springer Science+Business Media Dordrecht 2015

\section{Biblical Philosophy: an Introduction}

According to the traditional story of the development of Western thought, what we call philosophy originated in ancient Greece, where it existed for approximately 500 years without any relationship to biblical texts. ${ }^{1}$ What, however, are we to make of the fact that, for approximately 2000 years, from Philo and Justin the Martyr to Emmanuel Levinas and Charles Taylor, the Bible has been an integral part of the history of Western philosophy - a much longer period of time than the period in which it was not? Has the traditional account of the origins of philosophy adequately addressed the implications of this history when it insists that philosophy is primarily Greek - that philosophy originates in or is concerned primarily with, the ancient Greek conception of logos, rather than with modes of thought derived from other traditions (e.g., biblical faith)? Given, in other words, that the history of Western culture has, in the last 2000 years, never lost contact with the Bible in the way that its contact with the ancient Greeks did loosen, is it not possible that the Bible and its modes and objects of thought

\footnotetext{
${ }^{1}$ We here acknowledge that, empirically, there is no one Bible. Jews and Christians have different canons of texts, despite many shared ones; Catholics and Protestants have different canons, again despite many shared ones; Jews and Christians at different historical periods have had different canons of texts. It is also the case that the vast plurality of translations has, in some cases, produced significant differences in the meanings of texts. In this regard, we take an inclusive view and regard as 'biblical' any of the texts that have been canonized by these traditions. Such texts clearly bear a relationship to the other texts, are written within, in response to, and as interpretations of the context established by previous biblical texts. So, while a Jew may not accept the authority of Christian scriptures, it is undeniable that the figure of Jesus is offering an interpretation of Jewish law and scripture; a Protestant of some denomination may reject the so-called apocryphal books, but again it is undeniable that the Maccabean revolt is presented and thought about in I and II Maccabees in light of preceding biblical texts. Despite many important differences between these canons, as between texts within these canons, and even between episodes or even parts of episodes within these often polyvocal texts, there is a certain sense in thinking about them together and in rejecting the idea that complete homogeneity of viewpoint is the basis on which the integrity of a canon is established. In any case, with few exceptions, contemporary philosophy is practiced without reference to any of the texts anyone might be tempted to deem 'biblical.'
}

Mark Cauchi

mcauchi@yorku.ca

1 Department of Humanities, York University, 4700 Keele St, Toronto, Ontario M3J 1P3, Canada 
have had a greater impact on philosophy than is often assumed? What would uncovering the neglected relationship between the Bible and philosophy reveal about the concept, practice, and history of philosophy, as well as about particular concepts, practices, and movements within the history of philosophy?

Skeptics would no doubt respond to these questions by agreeing that the Bible has had an impact on philosophy - too much of an impact, in fact. Before philosophy was, allegedly, finally and fully disenchanted by Nietzsche, modern philosophers expended much too much energy thinking about things biblical, things that did not, so these skeptics believe, in fact merit such attention. By thinking about concepts like God, creation, theodicy, purposiveness, and miracles, philosophers would have fallen victim to Bacon's Idols of the Marketplace (about language) and the Theatre (about traditions of dogma) or to Wittgenstein's pseudo-problems, things that we believe exist simply because the words, habits of thought, and intellectual traditions exist, but that in reality do not.

Without ignoring that such a charge makes a number of assumptions - about what is reality, about whether such things agree with it, about whether what is not real on that definition merits philosophical attention, about what philosophy should do, and about what is philosophy - the deeper, more consequential problem, as we see it, is that, despite the acknowledgement of the factual presence of the Bible and things biblical in modern philosophy, the story of the latter continues to be told as if the Bible was somehow extraneous to what is modern and what is philosophical about modern philosophy. Modern philosophy, according to this story, is both modern and philosophical not through its relationship to the Bible but in spite of it or even in the critique of it. Consistent with what is called the 'secularization thesis' in the social sciences - that, as societies modernize, they secularize - the history of modern philosophy is told as a progressive disenchantment, what Charles Taylor pithily calls a 'subtraction story', ${ }^{2}$ where religious (but really biblical) illusion is slowly purged by reason until pure reason remains. It was, ironically, Nietzsche who taught us - although his lesson here is often not heeded - to see this idea as the fantastical superstition it is. For such an ahistorical narrative assumes that the reason which purges religion from itself does so without influence from the religion it purges and so exists ex nihilo, without a history. Nietzsche contrarily argues at the close of the Genealogy of Morals that it was Christian morality and its commitment to truth that, practiced ever more rigorously, eventually forbid belief in the lie of theism. ${ }^{3}$ As he says of theism, directly countering the subtraction story identified by Taylor, atheism is "not so much its remnant as its kernel. ${ }^{4}$

It is not Nietzsche's narrower focus on Christianity per se or on philosophy as atheistic that is our concern in this special issue. ${ }^{5}$ But Nietzsche's arguments about the historicity of reason and of atheism do open up the space to interrogate a positive

\footnotetext{
${ }^{2}$ Charles Taylor, A Secular Age (Cambridge, MA: The Belknap Press, 2007), 22, 26-27, 572-574.

${ }^{3}$ Friedrich Nietzsche, The Genealogy of Morals and Ecce Homo, ed. Walter Kaufmann (New York: Vintage Books, 1989), 160.

${ }^{4}$ Nietzsche, Ibid., 160.

${ }^{5}$ Indeed, Nietzsche himself recognized that to think deeply about Christianity's relationship to modernity necessitates thinking about the relationship of Christianity to biblical Judaism and to Christian scripture. See Avron Kulak, 'The Religious, the Secular, and the Natural Sciences: Nietzsche and the Death of God' in The European Legacy, 16.6, 2011.
} 
relationship between the Bible and modern philosophy. For, if philosophy is more indebted to the Bible than is usually recognized, then it would seem to suggest that either it is possible to philosophize about the Bible or the Bible is somehow philosophical in itself or both. In doing so, however, this biblical philosophy would not be, we want to be clear, equivalent to biblical theology, with no disrespect to the latter. While biblical theology demonstrates that it is possible to provide analytical articulations of biblical ideas and while theology contains within itself much profound philosophy, any theology is in the end committed to articulating and to justifying logically dogmas, foundational concepts, and customary practices. It thus places those dogmas, concepts, and practices above reason, making reason or philosophy, as they often were in the medieval university, 'handmaidens' of theology. Again taking a lesson from Nietzsche, we do not want to claim naively that a philosophy can proceed without any commitments or presuppositions at all-it cannot. Moreover, there should not be anything inherently wrong with being committed to or presupposing concepts, values, and practices derived from the Bible just because they come from the Bible. But we do want to claim that a true biblical philosophy must allow the philosophical analysis to go to the conclusions to which it is led and not to foreclose particular interpretations just because they contravene an overriding commitment.

We also think that a biblical philosophy should not merely be a philosophy of the Bible, at least not in the standard way the philosophy of $X$ formula in used in academic philosophy (as in philosophy of religion, philosophy of law, philosophy of film, etc.), where philosophy comes from outside to save the day. Such a model assumes that philosophy stands apart from the Bible and is unchanged by their encounter. While our use of the word 'philosophy' assumes and acknowledges that the practice it names has a relatively distinct identity and therefore an independence, we nevertheless think that philosophy's form and the subjects with which it concerns itself will have to morph and broaden in order to accommodate the Bible. So, to give a relatively simple example, one does not simply bring the classic philosophical arguments about the existence of God to bear on the representation of God in the Bible to determine whether such a God can or does exist, all the while assuming what existence means; one might instead carefully attend to the representation of the God in the Bible and clarify the nature of its existence, what the nature of its existence presupposes and implies, perhaps whether its existence is even a significant or relevant concern in the Bible, and, if not, what that suggests about that figure's presence in the text and its relationships to other beings. There are examples of how this might work in the history of philosophy, ${ }^{6}$ and the contributors in this special issue discuss some of the famous and less-known examples, as well as present some of their own approaches.

Without question, a major challenge in thinking through how to practice biblical philosophy is the nature of biblical textuality itself, which is clearly not written in the genre of modern philosophy. This is a challenge both for philosophically interpreting the Bible itself and for assessing those philosophers who do. With the exception of very few biblical texts that seem overtly philosophical (parts of the prophets, the Proverbs,

\footnotetext{
${ }^{6}$ One can cite, for instance, Spinoza's Theologico-Political Treatise, Hegel's discussions of biblical stories in the Lectures on the Philosophy of Religion and other texts, Kierkegaard's numerous engagements with scripture throughout his oeuvre, Nietzsche's discussion of the Gospels and Paul's letters in The Antichrist, and Heidegger's Phenomenology of Religious Life, among other more contemporary works cited in note 7 below.
} 
Lamentations, the Gospel of John, and some of the epistles), they are written for the most part in the forms of history, legend, biography, poetry and fiction, social and political critique, legal canon, and visionary fantasy, quite often being some mix of these. What does it mean to philosophize about such texts? What would it mean to claim that such texts were themselves philosophical? Such questions are not wholly new or limited to the relationship between philosophy and the Bible. Anyone engaged in working through the relationship between philosophy and any other forms of nonphilosophical expression faces the same fundamental problem. How, for instance, does one translate, if that is the right word, between a modern novel or a poem and philosophy or between a painting or a film and philosophy? We will not here in this introduction offer a methodology in answer to these questions, but we will point out that many modern philosophers have undertaken such translations before, whether it be Hobbes and Spinoza interpreting the Bible, Hegel interpreting visual art, Kierkegaard interpreting theatre, Nietzsche interpreting music, or twentieth-century philosophers like Derrida interpreting poetry, and Cavell and Deleuze interpreting cinema.

The papers gathered in this collection all tacitly or nearly agree with the conception of biblical philosophy sketched above, although their authors were at no point asked to sign on to it in the manner of a manifesto. ${ }^{7}$ We have an exemplary illustration of how philosophy can engage with the very textuality of the biblical texts, with neither discourse subordinated to the other, in Michael Fagenblat's contribution, 'Manifest Glory: Phenomenological Indications from the Hebrew Bible.' Fagenblat analyzes the ancient Hebrew syntagm, 'o Yhwh, usually translated as 'the glory of the LORD' or 'the Presence of the LORD,' which appears in numerous places throughout the Hebrew Bible, in the context of phenomenological theories of appearance and Heidegger's notion of 'formal indication.' Recounting how the phrase has been dealt with in Jewish theology and how the idea of the appearance of God or the absolute has been considered in modern philosophy, Fagenblat proceeds to show why 'The phenomenological thrust of biblical theology' - by which he means the Bible's own 'theology,' not the modern discourse - 'invites us to entertain the possibility that manifest divine glory - as luminous, majestic, awesome anthropos-is not a mere "projection," "representation" or "construction" of an idea but an aspect of God's own self-presentation.' Drawing links between this manifestation and the Kantian sublime, the Levinasian other, and Marion's saturated phenomenon, Fagenblat suggests that biblical divine manifestation provides a formal indication of how, within biblical thinking, all phenomena appear: all phenomena are glorious.

\footnotetext{
${ }^{7}$ In addition to this special issue, there has been a growing body of literature in recent years exploring the relationship between the Bible and philosophy. One of our own contributors, Brayton Polka, has written, Rethinking Philosophy in Light of the Bible: From Kant to Schopenhauer (London: Lexington Books, 2014). Besides his work, one can see: Alain Badiou, Saint Paul: The Foundation of Universalism, trans. Ray Brassier (Stanford, CA: Stanford University Press, 2003); Thomas L. Pangle, Political Philosophy and the God of the Bible (Baltimore: Johns Hopkins University Press, 2004); Giorgio Agamben, The Time that Remains: A Commentary on the Letter to the Romans, trans. Patricia Dailey (Stanford, CA: Stanford University Press, 2005); Michael Walzer, In God's Shadow: Politics in the Hebrew Bible (New Haven, CT: Yale University Press, 2012); Yoram Hazony, The Philosophy of Hebrew Scripture (Cambridge, UK: Cambridge University Press, 2012); Jaco Gericke, The Hebrew Bible and Philosophy of Religion (Society of Biblical Literature, 2014); Jean-Louis Chretien, Under the Gaze of the Bible, trans. John Marson Dunaway (Fordham, NY: Fordham University Press, 2014); and Davis Hankins, The Book of Job and the Immanent Genesis of Transcendence (Evanston, Il: Northwestern University Press, 2014).
} 
We have another example of biblical texts and philosophy coming into direct dialog in Avron Kulak's contribution, 'The World Is Not the Way It Is: The Twice Told Tales of Biblical Narrative.' In it, Kulak examines the relationship between biblical principles and modern western philosophy. Grounding itself in the double creation stories of Genesis and the double telling of the miracle of the loaves and fishes from the Gospel of Matthew, and contrasting these to ideas central to Plato, Kulak argues that western philosophers from Descartes to Kierkegaard explicitly understand their work to be rooted in the core values that underpin biblical narrative. The doubleness of these narratives, Kulak suggests, highlights the biblical authors' and texts' self-consciousness about their own telling and imagining of these stories. Recognizing that it is stories that are being told, rather than merely immediate presentations of reality, and that the content and hermeneutic nature of these is moral, the biblical texts show, as Kulak puts it, that the world is not the way it is, but is as it is only on the condition of intersubjective moral agents.

Where some readers may find Kulak's somewhat Spinozistic establishment of dialog and continuity between the Bible and the particular philosophers he focuses on easy to accept, to someone like Leo Strauss, who was skeptical of Spinoza's reconciliation of these discourses, the larger claim that modern thought is biblical may provoke doubt. Hence, the provocation set in Grant Haver's contribution, 'The Paradox of Politics: Leo Strauss's Biblical Debt to Spinoza (and Kierkegaard),' which argues that Strauss's thinking, despite his overt assertions that revelation and reason could never be reconciled, is nevertheless indebted, via Spinoza and Kierkegaard, to the Bible. As Havers outlines, where Strauss appreciated Spinoza's democratic liberalism, he rejected Spinoza's argument that democratic states must be founded on the biblical ethics of caritas and, instead, looks to classical philosophy for the defense and anticipation of liberalism. After looking at the contradictions and circuitous argumentative moves Strauss must make to defend this decision, Havers shows that, after all his vociferousness, Strauss is never able to defend his turn to Athens and that, if he wished to defend liberal democracy, he should have followed Spinoza and Kierkegaard and turned instead to Jerusalem.

Christopher Irwin similarly undertakes to show how a modern philosopher owes a debt to the Bible in his contribution, 'Reading Hannah Arendt as a Biblical Thinker.' Arendt's case is less circuitous than Strauss's, and so Irwin is able to argue more straightforwardly that Arendt can be considered a 'biblical thinker.' Irwin defines the latter concept carefully, claiming that it is 'not one who has to have any particular religious allegiance or motivations' but only 'one for whom concepts derived from biblical resources (biblical texts themselves, or traditions of biblical interpretation) play a crucial and even decisive role in [his or] her thinking.' After showing why the seemingly obvious place to look for evidence of her biblical thinking (her writings on Judaism) is not in fact the best place, Irwin goes on to show how the development of core Arendtian concepts, such as natality, action, plurality, and forgiveness, are all tied by her to biblical texts. Despite this fact, Irwin shows that Arendt will never fully acknowledge that the political philosophy she builds with these concepts is rooted not in Greek philosophy, as she claims, but in a biblical philosophy.

After these engagements with particular biblical texts and particular modern philosophers, our fittingly final contribution, Brayton Polka's essay, 'Modern Philosophy, the Subject, and the God of the Bible,' undertakes to recast in broad terms how we think 
about the history and the very project of modern philosophy as fundamentally and thoroughly biblical. Polka asserts that 'the modern revolution in philosophy, which runs for him from Descartes through to Kierkegaard, 'is centered in the thinking, willing, active, historical subject, the infinitely self-conscious human person, when and as distinguished from the finite object as found in the quantifiable space and time of the natural world.' This claim, in itself, may not surprise students of the history of philosophy, but Polka's second major and bold claim is that this subject is the divine and human subject of the Bible, that is, that the modern subject of philosophy carries on the conception and practice of subjectivity that is shared by both God and the human in the Bible. While Polka does not engage in detailed readings of biblical texts here, he offers throughout interlocked interpretations of a large suite of biblical concepts, such as God, creation, covenant, sin, redemption, love, and neighbor. Unpacking the paradoxes and dialectical logic embedded in the biblical idea that human beings are made in the image of God, knowing good and evil, Polka links this 'biblical logic of paradox' to his radical and innovative interpretation of the ontological argument, which he frames as a kind of deep structure of modernity. According to Polka, the ontological argument's claim to derive necessary divine existence from human thought implies that 'God, then, [is] that which exists, necessarily, in human thought, that is, [only] insofar as human beings think.' Polka argues forcefully that this deep structure of modernity, in which the absolute exists in thought, as well as its implications, cannot be aligned with what he argues is the contradictory structure of Greek thought.

Finally, it is our hope that this collection, far from being a final treatise on the relationship between the Bible and philosophy, opens the way for further research on philosophical interpretations of biblical texts, on historical philosophers' analyses of biblical texts, and essays on the methodology of biblical philosophy. The issue stands as a testament both to the innovative work of our contributors and to Sophia for offering a hospitable venue in which to bring these essays together. We are truly grateful to our contributors and to the editorial team of Sophia. 